\title{
Application of Flipped Classroom Based on Online Learning in University Business Administration Teaching
}

Ling Peng

Guangdong University Of Science \& Technology, 523083

Abstract: Business Administration is a sub-discipline of management, which mainly cultivates talents with knowledge and abilities in management, economics, law, business management, and production operations. With the development of Internet technology, the effective integration of online online learning and flipped classroom innovative teaching methods has enabled it to develop rapidly in college business management teaching, greatly improving the teaching efficiency of college business management subjects. This article puts forward some superficial suggestions based on the application of flipped classroom of online learning in business administration disciplines, in order to better improve the teaching quality of business administration disciplines in my country.

Keywords: Online Learning; Flipped Classroom; Business Management Teaching; Application Exploration

Online learning is a new model of online education based on Internet technology. Compared with traditional teaching methods, the degree of freedom is higher. The teaching content is also richer because there is no time limit. The "flipped classroom" is a new type of teaching mode, which transforms traditional teaching from "teaching first and then learning" into "first learning and then teaching", allowing students to clarify their learning goals through early learning, and then discover problems through independent thinking. Transferring the questions to the actual classroom allows teachers to answer intensively, which effectively improves classroom teaching efficiency. The two learning methods can be effectively combined to greatly enhance the autonomy of students in learning. It is a great tool for improving the effectiveness of teaching in various subjects in universities. Combining many years of business management teaching experience, the author studied the application of online learning flipped classroom in business management teaching based on the actual needs of students, aiming to provide students with better teaching services and improve their comprehensive quality.

\section{The function and characteristics of flipped classroom based on online learning}

\subsection{The role of online learning flipped classroom in actual teaching}

First, it allows learners to fully experience individualized learning. Compared with traditional teaching methods, "flipped classroom" truly realizes the student-centered teaching concept, transforming teachers from teaching teachers to guides, giving students more free learning space, and allowing students to learn Develop a good habit of independent learning. Secondly, it can effectively exert the learner's innovation ability. Based on the flipped classroom teaching of online learning, learners can combine freely according to abundant online teaching resources, and carry out targeted training and consolidation in combination with their own learning situation. Students can fully stimulate their learning potential in the learning process. Effectively enhance the learners' innovative ability and thinking ability. Finally, learners can fully enjoy the advantages of the integration of online learning and traditional teaching. Traditional teaching can give full play to the guiding role of teachers in teaching and make students learn more efficiently. On the other hand, online teaching can enable students to better exert their advantages in autonomous learning, and greatly enrich the

Copyright (C) 2020 Ling Peng

doi: 10.18282/le.v9i7.1491

This is an open-access article distributed under the terms of the Creative Commons Attribution Non-Commercial License

(http://creativecommons.org/licenses/by-nc/4.0/), which permits unrestricted non-commercial use, distribution, and reproduction in any medium, provided the original work is properly cited. 
content of traditional teaching classrooms. Flipped classroom teaching based on online learning can effectively combine the advantages of the two and help students achieve their own learning goals.

\subsection{The characteristics of the flipped classroom of online learning in actual teaching}

First, it has subverted traditional learning habits. The flipped classroom teaching model based on online learning completely overturns the traditional classroom teaching methods and student learning methods, advances the learning process, allows students to complete the initial grasp of new knowledge through self-study, and discovers their own understanding of knowledge through self-study The insufficiency of the follow-up classroom teaching goal is more clear, teachers have also become guides and explainers from traditional teaching, which greatly improves the learning efficiency of students.

Second, it releases the time and space constraints of learners. Flipped classroom based on online learning has fully released the teaching time and teaching space of traditional teaching, allowing learners to become more active and efficient in autonomous learning, and realizing the effective use of online teaching resources.

Third, it expands the learning resources of learners. Online online learning allows students to travel freely on the Internet, and it is easier to expand and extend online teaching content, so that some learners with their own ideas can learn more deeply, realize personalized education, and effectively make up for the shortcomings of traditional teaching It has greatly improved the effectiveness of education and teaching.

\section{Application of flipped classroom based on online learning in business administration teaching}

\subsection{Application analysis of pre-class learning}

Pre-class learning means that the teacher will show the teaching tasks to the students in advance, let the students learn by themselves through the teaching videos, and then complete the pre-class assessment so that they can understand the students' learning situation and carry out the teaching in a targeted manner. The main thing that should be paid attention to is the class. The release of pre-teaching videos. Based on the characteristics of online teaching, teaching videos can be roughly divided into two types. One is the public teaching video resources on the online learning platform. This type of video content is more sophisticated and comprehensive, but it lacks due characteristics and deep knowledge. Sex is not strong enough. The second is the teaching videos recorded by subject teachers according to the learning situation of students in the class. Although the production is lacking, the content is more targeted. Both have their own advantages and disadvantages. Teachers need to use them flexibly in combination with actual teaching situations to maximize the effectiveness of online teaching.

\subsection{Analysis of teaching application in class}

The main goal of the in-class teaching in the flipped classroom is the learning efficiency of teachers and students, and answers students' questions and doubts in the self-study stage before class, so that students can further improve and deepen their knowledge system. The important way to achieve this teaching goal is scenario simulation, which constructs a special teaching link according to the teaching content of business administration major to give full play to the learning potential of students in practical activities and enhance students' learning enthusiasm. In addition, teachers can further deepen the content of online learning, teach students in groups, encourage students to analyze and discuss, and improve their ability to answer questions..

\subsection{After class summary application analysis}

After the implementation of online learning flipped classroom teaching, teachers should also conduct a summary analysis of the students after class, combine the performance of the students in the learning process, and comment on the strengths and weaknesses of the students, so as to let the students understand their own deficiencies more clearly. Provide certain data support for the following learning and teaching. In addition, the business management major has a very strong timeliness. Teachers should follow up the teaching content in a timely manner in combination with current social events, and put forward new requirements for students in combination with after-school summaries, so that the course design of business management majors is more professional and effective. 


\section{Concluding remarks}

The online learning flipped classroom teaching model has had a great impact on the traditional teaching model, and both teachers and students need some time to adapt and adjust. Therefore, teachers and students should be guided by teaching to enable teachers and students to truly understand the advantages and characteristics of online learning flipped classroom teaching, and then implement targeted application practices based on the three stages of pre-class, in-class, and after-class, continuously summarize teaching experience, and improve flipped classroom Teaching design builds a better learning environment for students, effectively improves the teaching quality of business administration disciplines in universities, and cultivates more outstanding professionals with flexible and innovative capabilities.

\section{References}

1. Wang Jianchao, Huang Yun. Research on the application of flipped classroom based on micro-classes in Taekwondo teaching in colleges and universities[J]. Stationery and Sports Supplies and Technology, 2018, 001(001):64.

2. Gan Liangqin, Yang Shanggong, Zhou Chengxian, etc. The application of "micro-class" flipped classroom in college physics experiment teaching[J]. Laboratory Research and Exploration, 2018, v.37;No.264(02): 203-205+212.

3. Liang Shuang. Research on the Application of SAPs-based Flipped Classroom Teaching Mode in University Ideological and Political Education_ _ Taking University "Situation and Policy Course" as an Example [J]. Contemporary Educational Practice and Teaching Research, 2019(21): 18-19. 